\title{
Ritacestus gen. n. (Cestoda: Proteocephalidea) and redescription of $R$. ritaii comb. n., a parasite of Rita rita (Siluriformes) in India
}

\author{
Alain de Chambrier ${ }^{1}$, Tomáš Scholz ${ }^{2}$, Anirban Ash ${ }^{2}$ and Pradip Kumar Kar ${ }^{3}$ \\ ${ }^{1}$ Department of Invertebrates, Natural History Museum, P.O. Box 6434, CH-1211 Geneva 6, Switzerland; \\ ${ }^{2}$ Institute of Parasitology, Biology Centre of the Academy of Sciences of the Czech Republic \& Faculty of Science, University of \\ South Bohemia, Branišovská 31, 37005 České Budějovice, Czech Republic; \\ ${ }^{3}$ Jhargram Raj College, Jhargram, Paschim Medinipur, West Bengal 721507, India
}

\begin{abstract}
A new genus, Ritacestus, is proposed to accommodate Ritacestus ritaii (Verma, 1926) comb. n. (syn. Proteocephalus ritaii), a parasite of the catfish Rita rita (Hamilton) in India. The new genus, which is placed in the Gangesiinae, is characterized by (i) a small, subspherical scolex formed by four large lobes separated from one another by longitudinal grooves, with a large, widely oval to pyriform rostellum-like apical organ, larger than suckers and possessing an apical hemispherical depression; (ii) paramuscular and cortical position of some vitelline follicles (most follicles are situated medullary); (iii) ventral and dorsal bands of vitelline follicles usually uninterrupted ventral to terminal genitalia and reaching to the posterior margin of proglottides; (iv) the vagina always anterior to the cirrus-sac; (v) a large size of the body (length up to $51 \mathrm{~cm}$ ); and (vi) development of the uterus of type 2. In its morphology, especially shape of the scolex and apical organ, and paramuscular and cortical position of some vitelline follicles, Ritacestus resembles Postgangesia Akhmerov, 1969, but differs in the presence of a genital atrium (both genital pores of Postgangesia are separate), the anterior position of the vagina (almost always posterior in the latter genus), position of vitelline follicles in cross sections (dorsal and ventral bands in Ritacestus versus only a lateral band in the latter genus), and dorsal excretory canals indistinguishable in mature and gravid proglottides of $R$. ritaii (well developed in Postgangesia spp.). The type and only species of the genus, $R$. ritaii, is redescribed on the basis of new material from the type host from the Ganges River basin in India and its neotype is designated.
\end{abstract}

Keywords: morphology, taxonomy, neotype, Eucestoda, Gangesiinae, freshwater fish, Ganges River, India

A high number of tapeworms (Cestoda) of three orders (Caryophyllidea, Bothriocephalidea and Proteocephalidea) have been described from freshwater fish in the Indomalayan Region, with a great majority of them being based on material collected in India (for lists of species, see Mackiewicz 1981, Schmidt 1986, Hafeezullah 1993, Kuchta and Scholz 2007, Ash et al. 2011). Two cestode species have been placed in Proteocephalus Weinland, 1858, namely $P$. ritaii Verma, 1926 and $P$. vitellaris (Verma, 1928) (syn. Ichthyotaenia vitellaris Verma, 1928) (Verma 1926, 1928), but recent studies have provided evidence that this genus represents an artificial assemblage of morphologically dissimilar and phylogenetically unrelated taxa (de Chambrier et al. 2004a, Hypša et al. 2005).

Therefore, de Chambrier et al. (2004a) proposed the Proteocephalus aggregate to accommodate species parasitic in the Holarctic freshwater fish that share similar morphology (see Scholz and Hanzelová 1998) and form monophyletic clade (de Chambrier et al. 2004a, Hypša et al. 2005, Scholz et al. 2007). The remaining species of the Proteocephalus complex (= Proteocephalus sensu lato), especially those from other zoogeographical regions such as the Neotropical, Ethiopian and Indomalayan regions, actually do not belong to Proteocephalus sensu stricto (=Proteocephalus aggregate of de Chambrier et al., 2004) and should be placed in other genera.

In this paper, one of these species, Proteocephalus ritaii Verma, 1926, a parasite of the catfish Rita rita (Hamilton, 1822) (Siluriformes: Bagridae) in India, is redescribed on the basis of new material from the type host (type specimens could not be located) and a new genus is proposed to accommodate it.

\section{MATERIALS AND METHODS}

The present study is based on morphological evaluation of cestodes collected by the present authors from the intestine of Rita rita in two localities of West Bengal, India: (i) 12 wholemounts of three adult specimens (one without scolex) and 29 slides with cross sections from the Pagla River at Kaliachak near Malda (English Bazar $-24^{\circ} 51.65^{\prime} \mathrm{N} ; 88^{\circ} 01.08^{\prime} \mathrm{E}$ ), West Bengal, March 2 and 3, 2009, deposited in the Natural History Museum, Collection of Invertebrates, Geneva, Switzerland (acronym INVE), field numbers IND 66 (INVE 63249), 67 (INVE 
63242) and 132 (INVE 78786 and The Natural History Museum, London, UK; acronym BMNH - 2011.5.16.5); (ii) wholemounts of three adult specimens (one used for scanning electron microscopy - SEM) and two slides with longitudinal sections of the scolex from the Pagla River at Kaliachak, West Bengal, March 11, 13 and 27, 2011, field numbers IND 580 (INVE 78788), 684 (INVE 78789) and 909 (used for SEM); (iii) four whole-mounts of an adult specimen (without scolex) from the Ganges River at Farakka dam lake near Malda $\left(24^{\circ} 49.32^{\prime} \mathrm{N}\right.$; $87^{\circ} 56.49^{\prime} \mathrm{E}$ ), March 4, 2009, field number 145 (Institute of Parasitology, BC AS CR, České Budějovice, Czech Republic - acronym IPCAS C-603 and INVE 63240).

Cestodes collected by the present authors from fresh hosts were isolated from the intestine, rinsed in saline and immediately fixed with hot (almost boiling) 4\% formaldehyde solution (formalin), with pieces of several worms placed before in $99 \%$ molecular grade ethanol for DNA analysis. The specimens used for morphological observations were then stained with Mayer's hydrochloric carmine solution, dehydrated in a graded ethanol series, cleared with eugenol (clove oil), and mounted in Canada balsam. Pieces of strobila and one scolex were embedded in paraffin wax, sectioned at $12-15 \mu \mathrm{m}$ (cross sections of the strobila and longitudinal sections of the scolex), stained with Weigert's haematoxylin and counterstained with $1 \%$ eosin B with 1 drop of acetic acid/100 ml of solution (de Chambrier 2001). Technique of preparation of samples for SEM follows that described by Oros et al. (2010), whereas microthrix terminology follows that proposed by Chervy (2009). Eggs fixed with hot formalin together with worms for morphological study (see above) were studied in distilled water.

\section{RESULTS}

Examination of newly collected material of Proteocephalus ritaii from the type host has revealed several morphological characteristics, in which this species differs from all remaining congeneric taxa (species of Proteocephalus sensu stricto), but also from other proteocephalideans. To reflect a unique morphology of Proteocephalus ritaii, a new genus, Ritacestus, is proposed to accommodate this species, which is redescribed below.

\section{Ritacestus gen. $\mathrm{n}$.}

Diagnosis: Proteocephalidae, Gangesiinae. Testes, ovary, uterus and most vitelline follicles medullary; some vitelline follicles paramuscular and cortical. Large tapeworms, with massive strobila. Inner longitudinal musculature well developed, formed by single band of large bundles of densely packed muscle fibres. Ventral osmoregulatory canals wide; dorsal canals very narrow, distinguishable only in neck region and first immature proglottides. Scolex small, subspherical, without metascolex, with four wide lobes separated from one another by deep longitudinal grooves, and with widely oval to pyriform, rostellum-like apical organ, larger than suckers, with apical hemispherical depression; organ connected with neck region by large retractor muscles. Testes in one or two layers, forming two separate bands connected by a few testes in anterior third of proglottides. Genital pores irregularly alternating, slightly pre-equatorial. Genital atrium present. Ovary follicular, bilobed, with wide lateral lobes. Vagina anterior to cirrus-sac, with weakly developed circular vaginal sphincter. Vitelline follicles arranged in paired (ventral and dorsal) lateral bands from anterior to posterior margin of proglottides, usually uninterrupted at level of terminal genitalia. Uterine development of type 2 according to de Chambrier et al. (2004a), with welldeveloped uterine glands (chromophilic cells) alongside uterine stem and diverticula. Type and only species: Ritacestus ritaii (Verma, 1926) comb. $\mathrm{n}$.

Etymology: The generic names is composed of the host name ("Rita") and suffix "-cestus", which means a tapeworm; generic name should be treated as masculine.

Differential diagnosis: The new genus is placed in the Gangesiinae because of the presence of a large, rostellumlike apical organ connected with the neck region by retractor muscles, presence of vitelline follicles up to the posterior margin of proglottides, and medullary position of genital organs (testes, ovary, uterus and most vitelline follicles), with some vitelline follicles paramuscular and cortical (see de Chambrier et al. 2003).

The genus is characterized by combination of the following morphological characteristics (Figs. 1-23): (i) a subspherical scolex with a large, widely oval to pyriform rostellum-like apical organ with glandular content and with an apical hemispherical depression; apical organ larger than spherical suckers situated on large lobes separated from one another by four longitudinal grooves; (ii) position of vitelline follicles, most of which are situated in the medulla, but some are paramuscular and cortical; (iii) presence of paired (ventral and dorsal) bands of vitelline follicles, usually uninterrupted ventral to the terminal genitalia, reaching to the posterior margin of proglottides; (iv) anterior position of the terminal part of the vaginal canal in relation to the cirrus-sac; and (v) uterine development of type 2 (according to de Chambrier et al. 2004a).

Ritacestus is also characterized by a large size of the body (total length up to $51 \mathrm{~cm}$ ), which is composed of a high number (up to 800) of proglottides, a well-developed inner longitudinal musculature formed by large bundles of muscle fibres, a small vaginal sphincter, and conspicuous uterine glands (chromophilic, darkly stained cells alongside lateral diverticula of the uterus).

Ritacestus differs from all gangesiine genera, i.e. Electrotaenia Nybelin, 1942; Gangesia Woodland, 1924; Postgangesia Akhmerov, 1969; Silurotaenia Nybelin, 1942; and Vermaia Nybelin, 1942, by the type 2 of uterine development according to de Chambrier et al. (2004a) and by the presence of an apical depression on the top of the scolex (Figs. 1-3, 11, 19). Furthermore, it differs from all but one (Postgangesia) in the absence of hooks on the apical organ (present in the listed genera - Scholz et al. 1999, de Chambrier et al. 2003, 2004b, Ash et al. 

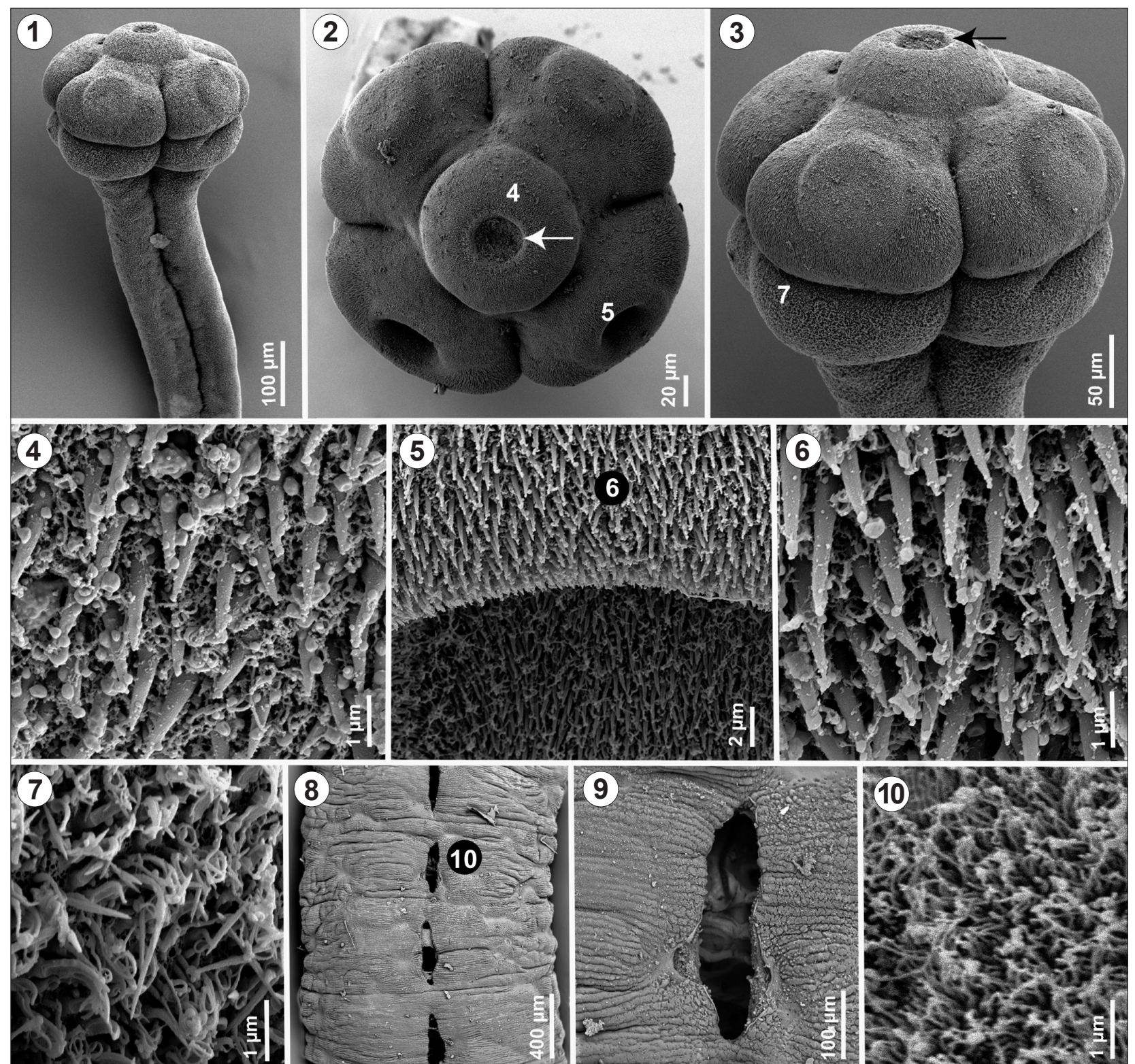

Figs. 1-10. Ritacestus ritaii (Verma, 1926) comb. n. from Rita rita, India. Scanning electron micrographs. Fig. 1. Scolex and neck region, dorsoventral view. Fig. 2. Scolex, apical view; note an apical hemispherical depression (arrow). Fig. 3. Scolex, dorsoventral view; note an apical hemispherical depression (arrow). Figs. 4-7. Microtriches (coniform spinitriches interspersed with capilliform filitriches) on the surface of apical organ (4), sucker cavity (5), external rim of suckers (6) and lobes of anterior part of neck (7), respectively. Figs. 8, 9. Uterine pores. Fig. 10. Microtriches (capilliform filitriches) on strobila. Note: small numbers in Figs. 2, 3, 5 and 8 correspond to the figures showing higher magnification images of marked regions.

2010). The new genus most closely resembles Postgangesia, which currently includes two species, P. orientalis Akhmerov, 1969 (type species) and P. inarmata de Chambrier, Al-Kallak et Mariaux, 2003, both parasitic in Silurus spp. (Siluriformes: Siluridae) in Palaearctic Asia (Fast East and Middle East, respectively - de Chambrier et al. 2003). Species of both genera possess a scolex with a rostellum-like apical organ of a very similar shape, with powerful muscular retractors, but devoid of hooks (see figs. 1 and 3 in de Chambrier et al. 2003) and vitelline follicles present also between muscle bundles of the inner longitudinal musculature (paramuscular) or entirely in the cortex (de Chambrier et al. 2003).

Besides a different uterine development and presence/ absence of an apical hemispherical depression, both genera can be differentiated from each other in a number of morphological characteristics, such as: (i) male and female genital pores of Postgangesia spp. are separated (see figs. 2 and 4 in de Chambrier et al. 2003), whereas the cirrus-sac and vagina open into a deep genital atrium 
in $R$. ritaii (Fig. 13); (ii) vitelline follicles form only one lateral band in $P$. orientalis and $P$. inarmata on both sides (see figs. 5, 6, 16 and 17 in de Chambrier et al. 2003), whereas two pairs (ventral and dorsal ones) are present on both sides of proglottides of $P$. ritaii (Figs. 21-23); (iii) the vagina is always anterior to the cirrus-sac in Ritacestus (Figs. 12-14), but it is usually posterior in Postgangesia spp. (anterior in only $4-15 \%$ of proglottides); (iv) dorsal osmoregulatory canals are indistinguishable in mature, pregravid and gravid proglottides of $R$. ritaii (see Figs. 21-23) (but present, well developed in $P$. orientalis and $P$. inarmata; see fig. 5 for $P$. inarmata in de Chambrier et al. 2003); (v) vaginal sphincter, yet weakly developed and small (Fig. 13), is present in R. ritaii, but absent in both species of Postgangesia (see figs. 2 and 6 in de Chambrier et al. 2003).

Remarks. Placement of the new genus in the Gangesiinae is based mainly on the characters discussed by de Chambrier et al. (2003), who provided new data on the morphology of members of this subfamily, which includes parasites of siluriform fish in the Palaearctic, Indomalayan and Ethiopian zoogeographical regions (Rego 1994, Rego et al. 1998). The most important diagnostic character, which is shared by all members of the Gangesiinae, including Ritacestus, is the presence of a large, rostellum-like apical organ (with retractor muscles), which may be armed with hooks and hooklets (absent in Postgangesia and Ritacestus). All gangesiine cestodes have vitelline follicles medullary, but follicles may penetrate between the inner longitudinal musculature into the cortex in species of Gangesia, Postgangesia and Ritacestus (de Chambrier et al. 2003; present study).

The presence of type 2 of uterine development in Ritacestus is unique within the Gangesiinae, but more data are necessary for a better understanding of the evolution of the uterus in the Proteocephalidea (de Chambrier et al. 2004a). It should also be pointed out that the current classification of proteocephalideans and their subfamilies, based on W.N.F. Woodland's concept (see Freze 1965, Rego 1994), i.e. on the position of the genital organs in relation to the inner longitudinal musculature, has been questioned by phylogenetic studies using morphological (Rego et al. 1998) and molecular data (de Chambrier et al. 2004a, Hypša et al. 2005). These data also cast doubts upon circumscription of individual genera, but molecular analyses invariably demonstrated that gangesiine cestodes represent, together with the Acanthotaeniinae, the most basal group of the Proteocephalidea.

Besides a number of morphological characteristics, erection of the new genus is also supported by molecular data (partial sequences of the 28S rRNA gene - J. Mariaux, unpublished data; work in progress). In preliminary analyses, $R$. ritaii formed a separate clade at the base of the phylogenetic tree of the Proteocephalidea (data not shown), thus being distant from, and unrelated to, any of the taxa currently placed in Proteocephalus sensu lato (see de Chambrier et al. 2004a).

Ritacestus ritaii (Verma, 1926) comb. n. Figs. 1-23 Syn.: Proteocephalus ritaii Verma, 1926 (misspelled as P. ritai or P. ritae - see Freze 1965).

Redescription (based on 7 specimens from West Bengal, India with measurements in micrometres unless otherwise indicated; data of Verma 1926 in parentheses): Proteocephalidae, Gangesiinae. Large tapeworms, 170 513 (125) $\mathrm{mm}$ long and up to 3.17 (3) $\mathrm{mm}$ wide. Strobila consisting of $317-814(600-1,000)$ acraspedote proglottides: 184-404 immature, 9-13 mature and 120-403 pregravid and gravid. Immature proglottides much wider than long to almost rectangular; mature proglottides few in number, wider than long to rectangular (Fig. 12); pregravid and gravid proglottides variable in shape (Fig. 14), usually wider than long.

Longitudinal internal musculature well developed, formed by single band of large bundles of densely packed muscle fibres (Figs. 21-23). Subtegumental muscles well developed. Ventral osmoregulatory canals wide, thinwalled, median to vitelline follicles (Figs. 12, 21-23). Dorsal osmoregulatory canals very narrow, sinuous, thick-walled, distinguishable only in neck region and first immature proglottides.

Scolex small, subspherical, wider than neck (Figs. 1-3, 11, 18-20), 235-245 (144) long and 355-370 (224) wide, with large, widely oval to pyriform apical organ with granular content (Figs. 19, 20). Apical organ 85-110 long and 115-125 wide, larger than suckers, connected by several muscle bundles (retractors) to neck region (Figs. 11, 19, 20), surrounded by gland cells with long ducts opening around apical cavity (Fig. 19), with apical hemispherical depression, about 30 in diameter (Figs. 1-3, 5, 11, 19). Suckers spherical, 90-105 (45) in diameter, situated on large lobes separated from one another by four deep longitudinal grooves (Figs. 2, 11). Surface of scolex covered with coniform spinitriches interspersed with capilliform filitriches of different size and density, largest spinitriches being on outer margin (external rim) of suckers (Figs. 4-7). Neck (proliferative zone) 150-190 wide, uniformly covered, similarly as strobila, with capilliform filitriches (Fig. 10).

Testes medullary, spherical to oval, 35-80 long and 26-60 wide (40-60 in diameter), 128-179 (150-200) in number, in one or two incomplete layers (Figs. 21, 22), forming two separate fields usually connected with a few testes in anterior third of proglottides (Figs. 12, 14). Testes present also in last gravid proglottides (Fig. 14). Vas deferens coiled, reaching to midline of proglottis (Figs. $12,14)$. Cirrus-sac widely pyriform to subspherical (Fig. 13), thin-walled, relatively small, 130-230 (192) long by $60-120$ (128) wide, its length representing only 


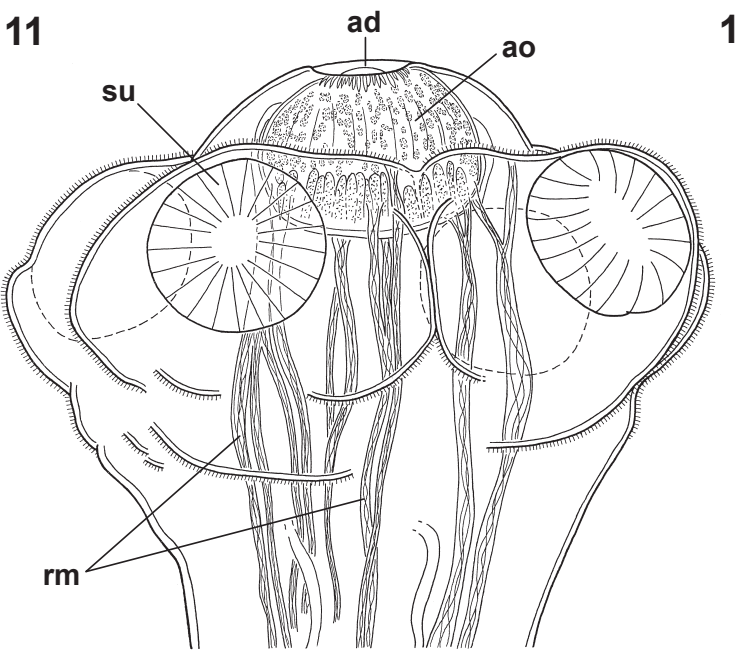

$100 \mu \mathrm{m}$

13

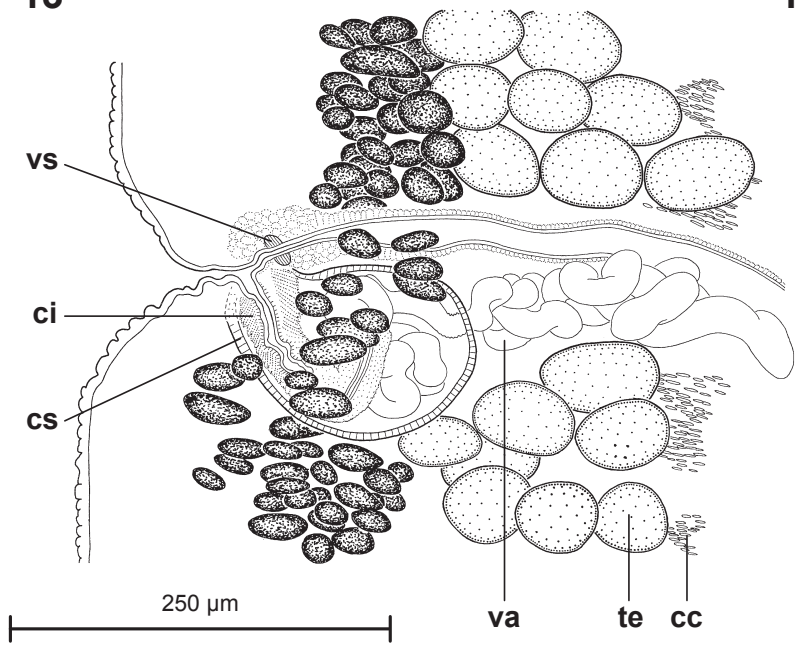

12
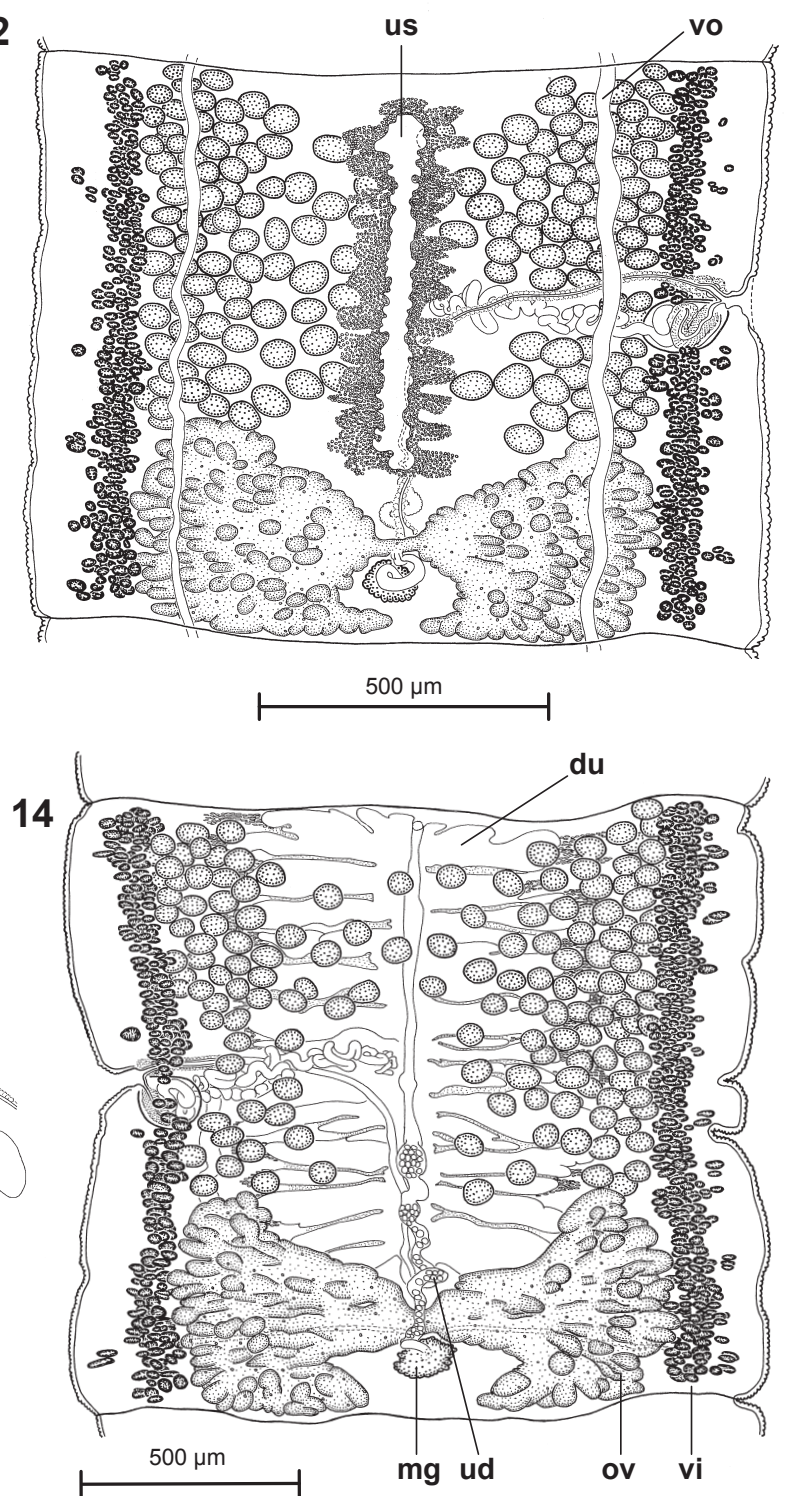
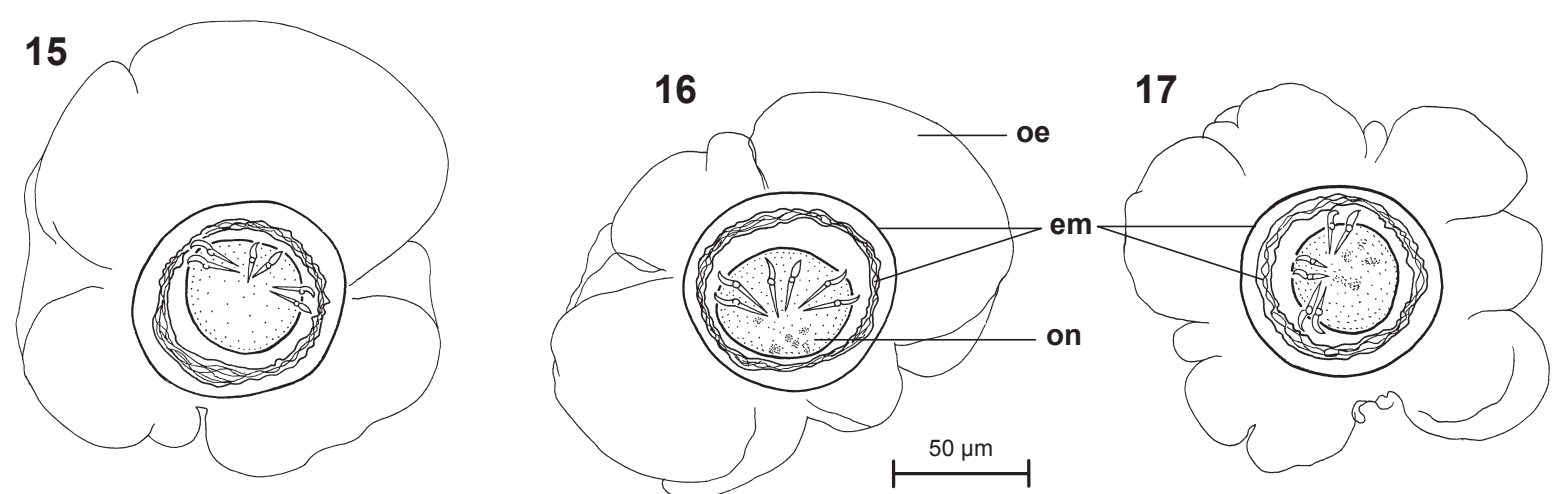

Figs. 11-17. Ritacestus ritaii (Verma, 1926) comb. n. from Rita rita, India. Fig. 11. Scolex, dorsoventral view (neotype-INVE 63242). Fig. 12. Mature proglottis, ventral view (IPCAS C-603). Fig. 13. Terminal genitalia, dorsal view (IPCAS C-603). Fig. 14. Gravid proglottis, dorsal view (IPCAS C-603). Figs. 15-17. Eggs drawn in distilled water. Abbreviations: ad - apical depression; ao - apical organ; cc - chromophilic cells on the apex of diverticula of uterus; ci - cirrus; cs - cirrus-sac; em - embryophore; mg - Mehlis' gland; oe - outer envelope; on - oncosphere; ov - ovary; rm - retractor muscles; su - suckers; te - testes; ud - uteroduct; us - uterine stem; va - vas deferens; vi - vitelline follicles; vo - ventral osmoregulatory canal; vs - vaginal sphincter. 
$10-14 \%$ (mean $=12 \%, \mathrm{n}=30$, coefficient of variability $[\mathrm{CV}$, i.e. standard deviation divided by mean $]=12 \%$ ) of proglottis length. Internal sperm duct thin-walled, coiled; ejaculatory duct thick-walled; cirrus unarmed, occupies about half-length of cirrus-sac (Fig. 13). Genital pore alternating irregularly, pre-equatorial, situated at 29-50\% (mean $=42 \%, \mathrm{n}=30, \mathrm{CV}=12 \%)$ of proglottis length from anterior margin (Figs. 12, 14). Genital atrium narrow, deep (Fig. 13).

Ovary bilobed, follicular, with wide lateral wings of irregular shape (Figs. 12, 14, 23). Width of ovary 190 555 , which represents $34-55 \%$ (mean $=45 \%, \mathrm{n}=58$, $\mathrm{CV}=13 \%$ ) of proglottis width. Vagina straight in distal part, always anterior to cirrus-sac, crossing vas deferens ventrally between cirrus-sac and mid-line of proglottis (Figs. 12-14), with terminal part near genital atrium surrounded by dark stained (chromophilic) cells and small, weakly developed circular vaginal sphincter (Fig. 13). Vitelline follicles medullary, with several follicles penetrating between muscle bundles of inner longitudinal musculature, thus being paramuscular, and a few follicles cortical (Figs. 21-23). Vitelline follicles arranged in narrow, paired (dorsal and ventral) bands on both sides of proglottides, occupying almost its total length, 96-100\% on aporal side and $97-100 \%$ on poral side (Figs. 12, 14, 21-23). Bands usually uninterrupted at level of terminal genitalia, with vitelline follicles often present also ventral and dorsal to cirrus-sac and vagina (Figs. 13, 14, 21).

Uterus with development of type 2 according to de Chambrier et al. (2004a). In immature proglottides, uterine stem first appears as wide longitudinal concentration of chromophilic cells (uterine glands) along median line, gradually extending laterally (Figs. 12, 21, 22). Lumen of uterus appears in last immature proglottides; uterine glands occupy up to $28 \%$ of proglottis width at this stage of development. Eggs appear soon after first appearance of spermatozoides in vas deferens. In gravid proglottides, lateral diverticula (outgrowths) occupy up to $75 \%$ of proglottis width, numbering 9-18 (8-12) on each side (9-17 on poral side and $10-18$ on aporal side), lined with wide band of uterine glands (Fig. 22). Uterus opening by large, slit-like uterine pores on ventral side of proglottides (Figs. 8, 9).

Eggs with hyaline outer envelope 40-60 in diameter; embryophore thick, spherical, 23-25 in diameter [Verma (1926), who reported diameter of "ova" to be 16 , may have referred to oncosphere], consisting of two layers, outer transparent layer and nuclei-containing inner envelope. Oncospheres widely oval, 14-16 long and 12-14 wide, with three pairs of embryonic hooks 6.5-8 long (Figs. 15-17).

Type host: Rita rita (Hamilton, 1822) (Siluriformes: Bagridae).

Type locality: Ganges and Jumna (= Yamuna) rivers, northern India (exact locality not provided).
Type material: Not known to exist; therefore, a complete specimen from $R$. rita from the Pagla River at Kaliachak, West Bengal, collected on March 2, 2009 (host field number IND 67), is designated as neotype and deposited in the helminthological collection of the Natural History Museum in Geneva (INVE 63242).

Site of infection: Anterior intestine.

Prevalence: Kaliachak: $50 \%$ in 2009 and $19 \%$ in 2011 ( $n=6$ and 16 fish examined, respectively; intensity of infection 1-3 tapeworm [mean 1.3]); Farakka dam lake: $9 \%$ in 2009 ( $\mathrm{n}=11 ; 1$ tapeworm), but not found in any of 18 R. rita examined in 2011. Verma (1926), who dissected about 100 catfish, reported a prevalence of $10 \%$; he also mentioned that fish smaller than 10-12 inches, i.e. about 25.5$30.5 \mathrm{~cm}$, were never infected. In West Bengal, infected fish measured $30-39.5 \mathrm{~cm}$ in total length (negative fish measured $25-42.5 \mathrm{~cm})$.

D i s tribution: India - Uttar Pradesh and West Bengal (new geographical record).

Remarks. Ritacestus ritaii was described as Proteocephalus ritaii by Verma (1926) on the basis of several specimens (but only 3 with scolex) found in the catfish Rita rita from the Ganges and Jumna (= Yamuna) rivers, most probably near Allahabad. Verma (1926) did not describe several characteristics of taxonomic importance, including scolex morphology, in sufficient detail. The apical organ was also described briefly and incorrectly by Verma (1926).

In the original description, the scolex, including surface of the suckers, was described to be devoid of any structures such as spines ("The suckers .... like all other parts of the scolex, are unarmed possessing neither spines nor spine-lets" - Verma 1926). SEM observation based on new material provided first data on surface structures and documented the presence of coniform spinitriches of different size and density (largest spinitriches cover outer rims of suckers - Fig. 6) interspersed with capilliform filitriches on the scolex, whereas the neck region and strobila are uniformly covered with capilliform filitriches only. In other gangesiine cestodes, microtriches have been studied in more detail using SEM only in Silurotaenia siluri from European wels (Silurus glanis L.) by Scholz et al. (1998), who also found coniform spinitriches interspersed with capilliform filitriches on the scolex and capilliform filitriches on the neck and strobila (individual types and subtypes of microtriches were named in a different way from that used in the present paper, which follows terminology just recently proposed by Chervy 2009).

The only specimen available for SEM observation (Figs. 1-10) possesses, besides a four-lobed scolex, with suckers on each lobe (Fig. 2), four lobes posterior to the scolex proper (Figs. 1, 3). However, it is evident from the appearance of both stained, mounted specimens with intact scolex (neotype - Fig. 11; voucher - INVE 78786, data not shown), longitudinal sections of another scolex (INVE 63240; Figs. 18-20) and the absence of coniform 
de Chambrier et al.: Ritacestus gen. n.
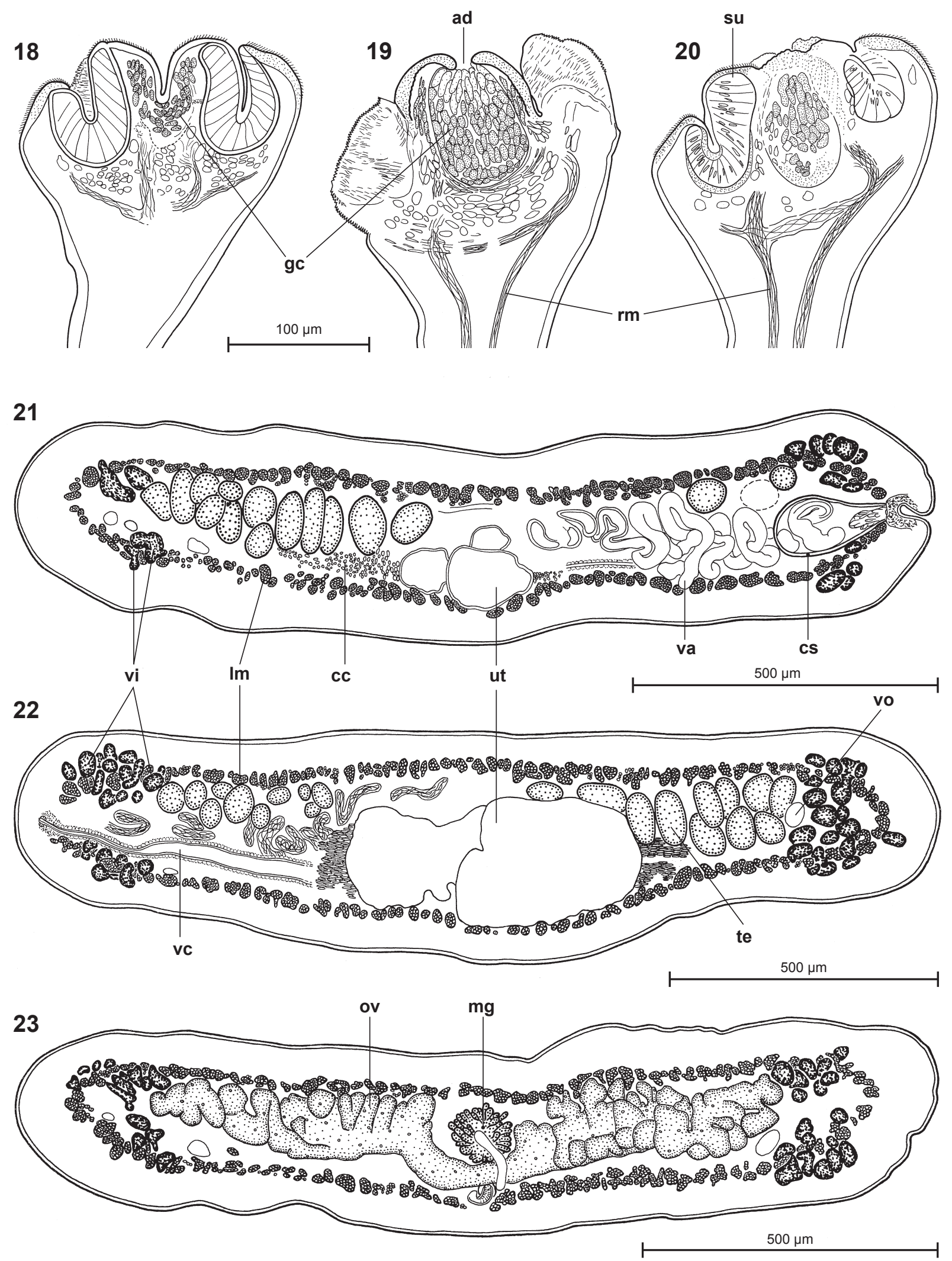

Figs. 18-23. Ritacestus ritaii (Verma, 1926) comb. n. from Rita rita, India. Figs. 18-20. Longitudinal sections of the scolex (INVE 78789). Figs. 21-23. Cross sections at level of cirrus-sac, uterus and ovary, respectively (INVE 78786). Abbreviations: ad - apical depression; cc - chromophilic cells on the apex of diverticula of uterus; cs - cirrus-sac; gc - glandular cells; lm - internal longitudinal musculature; mg - Mehlis' gland; ov - ovary; rm - retractor muscles; su - suckers; te - testes; ut - uterus; va - vas deferens; vc - vaginal canal; vi - vitelline follicles; vo - ventral osmoregulatory canal (anastomosed). 
spinitriches on these lobes (coniform spinitriches are present on lobes of the scolex - Figs. 3-6) that they represent neither a metascolex nor posterior lobes of the scolex proper. They probably represent the folded anterior part of the neck region (proliferation zone); such a zone, yet weakly developed, can be distinguished in the neotype (Fig. 11).

Vitelline follicles were reported to be medullary only (Verma 1926), but the present study provided evidence that follicles may be also paramuscular and cortical. Verma (1926) also did not describe correctly osmoregulatory canals, because he did not observe the dorsal canals at all ("The excretory system consists of two main longitudinal vessels situated ventrally"). The present study has demonstrated that the dorsal canals are present posterior to the scolex, but diminish in the first immature proglottides, being indistinguishable in mature, pregravid and gravid proglottides in all seven specimens available, even in their cross sections (Figs. 21-23).

Verma (1926) reported the presence of a well-developed inner longitudinal musculature, which is formed by one layer of large bundles of numerous, densely packed muscle fibres. So well developed musculature is relatively rare among proteocephalideans, but it may be related to the large size of $R$. ritaii, because it has been observed also in other large-sized proteocephalideans, such as Thaumasioscolex didelphidis Cañeda-Guzmán, de Chambrier et Scholz, 2001 from opossum in Mexico, which is up to $105 \mathrm{~cm}$ long, and Barsonella lafoni de Chambrier, Scholz, Beletew et Mariaux, 2009 from Clarias catfish in Africa, with the body length up to $17 \mathrm{~cm}$ (Cañeda-Guzmán et al. 2001, de Chambrier et al. 2009).

The species name of $R$. ritaii has been spelled in different ways by several authors, such as "ritai", "ritae" or "ritaii" (see Freze 1965), but the correct spelling should be "ritaii" according to the International Code of Zoological Nomenclature (Articles 32.2 and 32.5).

\section{DISCUSSION}

Proteocephalus is the most speciouse genus of proteocephalidean cestodes, with 91 described species according to Schmidt (1986), but it represents undoubtedly an artificial assemblage of unrelated species. In the most comprehensive phylogenetic analysis inferred from partial sequences of the 28S rRNA gene (de Chambrier et al. 2004a), 16 sequenced species of Proteocephalus appeared in as many as seven unrelated clades, and a multigene analysis by Hypša et al. (2005), based on comparison of sequences of ITS-2 and three mitochondrial and nuclear genes (16S, 18S and 28S rRNA), resulted in placement of 17 Proteocephalus spp. in five distant, unrelated groups.

Species of Proteocephalus parasitic in teleost fish in the Palaearctic Region were placed in the Proteocephalus aggregate to reflect monophyly of this group (de Cham- brier et al. 2004a) and similar morphology of its species (Scholz and Hanzelová 1998, Scholz et al. 2007). Current studies of the present authors (de Chambrier et al. 2007, 2011, Scholz et al. 2009) have also demonstrated that Proteocephalus spp. from African siluriform fish may form a monophyletic clade distant from the Proteocephalus aggregate, because they are dissimilar in several morphological characteristics, the most conspicuous differences from Palaearctic species being the shape of the eggs, scolex morphology and development of the inner longitudinal musculature.

The present study provides evidence that generic placement of $P$. ritaii is no more acceptable. Previously, most species with a spherical or globular scolex, four unarmed suckers and testes in one field were usually placed in Proteocephalus, even though they parasitize unrelated groups of hosts in different zoogeographical regions (Freze 1965, Schmidt 1986). The proposed transfer of Verma's (1926) species to a new genus supports the conclusion of de Chambrier et al. (2004a), who wrote on p. 163: "The present classification scheme is no longer satisfactory, and an alternative structure for the genus must be defined."

The type and only host of $R$. ritaii was placed in the Bagridae, but recent studies demonstrate that this catfish represents a separated lineage within the Siluroidei, being much more related to plotosids than to bagrids (Sullivan et al. 2006). Rita rita is an economically important fish, which also occurs in Afghanistan, Pakistan, Nepal and Bangladesh. Rita is composed of six species, namely $R$. chrysea Day, R. gogra (Sykes), R. kuturnee (Sykes), $R$. macracanthus $\mathrm{Ng}, R$. rita (Hamilton) and $R$. sacerdotum Anderson (Froese and Pauly 2011). Among these, $R$. chrysea, $R$. gogra and $R$. kuturnee are endemic to peninsular India and $R$. sacerdotum to Myanmar. Rita macracanthus is reported from Afghanistan, Pakistan and north-western India. None of the above mentioned five species, as per our knowledge, has been reported to host cestode parasites.

Besides $R$. ritaii, no other proteocephalidean cestode has been found in $R$. rita, but monozoic tapeworms, namely Gephyrolina paragonophora (Woodland, 1923) (syn. Pseudogephyrolina guptai Gupta et Singh, 1992 see Gibson 1994) (Amphilinidea), Pseudocaryophyllaeus indicus Gupta, 1961 [= Pseudocaryophyllaeus tenuicollis (Bovien, 1926)] and P. ritai Gupta et Singh, 1983 (both Caryophyllidea), were reported from this catfish (Gupta and Singh 1983, 1992). However, the two latter cestodes are specific parasites of the walking catfish, Clarias batrachus (L.), and $R$. rita represents only incidental or atypical host (see Ash et al. 2011). In addition, unidentified "pseudophyllidean" larvae (most probably of the order Bothriocephalidea) were reported from $R$. rita in Bangladesh (Khanum et al. 2008). The present authors examined $51 R$. rita from India and Bangladesh but never found any other cestode than $R$. ritaii. 
The second species of "Proteocephalus" (= Proteocephalus sensu lato; see de Chambrier et al. 2004a) from freshwater fish in India, P. vitellaris Verma, 1928, described from the sisorid catfish Bagarius yarrelii (Sykes), also possesses a conspicuous apical organ and its strobila is similar to that of $R$. ritaii, except for the distribution of lateral bands of vitelline follicles, which are bent inwards near the posterior margin of proglottides in P. vitellaris (see Verma 1928). However, redescription of $P$. vitellaris is pending because its original description was based on strongly flattened specimens and several morphological data of taxonomic importance were not provided by Verma (1928).

In March 2009, one specimen apparently conspecific with P. vitellaris was found in Bagarius bagarius (Hamilton) in the Ganges River at Farakka dam lake, West Bengal by the present authors (unpublished data). Although this tapeworm was immature, the morphology of its scolex, especially the presence of a large apical organ, resembles that of $R$. ritaii. It is thus possible that this species also belongs to Ritacestus, but new material is necessary before any taxonomic action is proposed.
Acknowledgments. The authors are deeply indebted to two anonymous reviewers, who provided very helpful suggestions and insightful remarks, to Dr. Mikuláš Oros (Košice, Slovakia) for invaluable help during collecting trip in India in 2011, to Dr. Jean Mariaux (Natural History Museum, Geneva) for providing unpublished data on the phylogenetic position of Ritacestus ritaii, and to Dr. Céline Levron, Martina Borovková, Blanka Škoríková (all Institute of Parasitology, České Budějovice), Florence Marteau, Janik Pralong and Gilles Roth (all Natural History Museum, Geneva) for excellent technical help. This study forms part of $\mathrm{PhD}$ studies of A.A., who expresses his gratitude to Jayanta Choudhury for help. Stays of T. S. and A. A. in India in 2009 and 2011 were realized under the Indian National Science Academy (INSA) - Academy of Sciences of the Czech Republic Bilateral Exchange Programme and with support of the Jhargram Raj College in Jhargram, Paschim Medinipur, West Bengal. These stays were also supported by the Institute of Parasitology (research projects Nos. Z60220518 and LC 522), Grant Agency of the Czech Republic (projects Nos. 524/08/0885 and 206/09/H026), and the National Science Foundation, USA (PBI award Nos. 0818696 and 0818823). Special thanks are due to Amritendu Mondal, Debsekhar Nath, Tinkori Bhui, Sanatan Murmu and Sourav Sarkar for invaluable help during collecting fish and their parasitological examination.

\section{REFERENCES}

Ash A., de Chambrier A., Scholz T., Kar P.K. 2010: Redescription of Vermaia pseudotropii, a hyperapolytic freshwater tapeworm, and composition of Vermaia Nybelin, 1942 (Cestoda: Proteocephalidea). Rev. Suisse Zool. 117: 665-677.

Ash A., Scholz T., Oros M., Kar P.K. 2011: Tapeworms (Cestoda: Caryophyllidea), parasites of Clarias batrachus (Pisces: Siluriformes) from the Indomalayan region. J. Parasitol. 97: 435-459.

Cañeda-Guzmán I.C., de Chambrier A., Scholz T. 2001: Thaumasioscolex didelphidis n. gen. and n. sp. (Cestoda: Proteocephalidae) from the black-eared opossum Didelphis marsupialis from Mexico, the first proteocephalidean tapeworm from a mammal. J. Parasitol. 87: 639-647.

De Chambrier A. 2001: A new tapeworm from the Amazon, Amazotaenia yvettae n. gen., n. sp. (Eucestoda: Proteocephalidea) from the siluriform fishes Brachyplatystoma filamentosum and B. vaillanti (Pimelodidae). Rev. Suisse Zool. 108: 303-316.

de Chambrier A., Al-Kallak S.N.H., Mariaux J. 2003: A new tapeworm, Postgangesia inarmata n. sp. (Eucestoda: Proteocephalidea: Gangesiinae), parasitic in Silurus glanis (Siluriformes) from Iraq and some comments on the Gangesiinae Mola, 1929. Syst. Parasitol. 55: 199-209.

de Chambrier A., Scholz T., Beletew M., Mahmoud Z.N. 2007: Redescription of Proteocephalus sulcatus (Klaptocz, 1906) (Cestoda: Proteocephalidea), a poorly known parasite of Clarotes laticeps (Pisces: Siluriformes) in Africa. Rev. Suisse Zool. 114: 693-702.

de Chambrier A., Scholz T., Beletew M., Mariaux J. 2009: A new genus and species of proteocephalidean (Cestoda) from Clarias catfishes (Siluriformes: Clariidae) in Africa. J. Parasitol. 95 : $160-168$.

de Chambrier A., Scholz T., Ibraheem M.H. 2004b: Redescription of Electrotaenia malopteruri (Fritsch, 1886) (Cestoda: Proteocephalidae), a parasite of Malapterurus electricus (Sil- uriformes: Malapteruridae) from Egypt. Syst. Parasitol. 57: 97-109.

de Chambrier A., Scholz T., Mahmoud Z.N., Mariaux J., JirKŮ M. 2011: Tapeworms (Cestoda: Proteocephalidea) of Synodontis spp. (Siluriformes) in Africa: survey of species and their redescriptions. Zootaxa 2976: 1-14.

de Chambrier A., Zehnder M.P., Vaucher C., Mariaux J. 2004a: The evolution of the Proteocephalidea (Platyhelminthes, Eucestoda) based on an enlarged molecular phylogeny, with comments on their uterine development. Syst. Parasitol. 57: 159-171.

Chervy L. 2009: Unified terminology for cestode microtriches: a proposal from the International Workshops on Cestode Systematics in 2002-2008. Folia Parasitol. 56: 199-230.

FreZE V.I. 1965: [Proteocephalata in Fish, Amphibians and Reptiles.] Essentials of Cestodology. Vol. V. Nauka, Moscow, 538 pp. (In Russian; English translation, Israel Program of Scientific Translation, 1969, Cat. No. 1853, v +597 pp.)

Froese R., Pauly D. (Eds.) 2011: FishBase. World Wide Web electronic publication, www.fishbase.org, 08/2011.

Gibson D.I. 1994: Order Amphilinidea Poche, 1922. In: L.F. Kha1il, A. Jones and R.A. Bray (Eds.), Keys to the Cestode Parasites of Vertebrates. CAB International, Wallingford, pp. 3-10.

Gupta V., Singh S.R. 1983: On a new species Pseudocaryophyllaeus ritai sp. nov. (family: Caryophyllaeidae) from the intestine of a freshwater fish, Rita rita from river Gomati at Lucknow, U.P. Ind. J. Helminthol. 34: 11-14.

Gupta V., Singh S.R. 1992: On a new cestode Pseudogephyrolina guptai gen. et sp. nov. from a freshwater fish Rita rita from Lucknow. Ind. J. Helminthol. 43: 96-99.

Hafeezullah M. 1993: Caryophyllidean Cestode Fauna of India. Records of the Zoological Survey of India, Occasional paper No. 157, 101 pp.

HYPŠA V., ŠKEŘíKOVÁ A., Scholz T. 2005: Multigene analysis and secondary structure characters in a reconstruction of phylog- 
eny, evolution and host-parasite relationship of the order Proteocephalidea (Eucestoda). Parasitology 130: 359-371.

Khanum H., Ferdows J., Farhana R. 2008: Community of helminth parasites in Rita rita (Hamilton Buchanun). J. BioScience 16: 133-135.

Kuchta R., Scholz T. 2007: Diversity and distribution of fish tapeworms of the "Bothriocephalidea" (Eucestoda). Parassitologia 49: 129-146.

MACKIEWICZ J.S. 1981: Synoptic review of the Caryophyllidea (Cestoidea) of India, Pakistan and Nepal. Himalayan J. Sci. 1: 1-14.

Oros M., Scholz T., Hanzelová V., Mackiewicz J.S. 2010: Scolex morphology of monozoic cestodes (Caryophyllidea) from the Palaearctic Region: a useful tool for species identification. Folia Parasitol. 57: 37-46.

Rego A.A. 1994: Order Proteocephalidea Mola, 1928. In: L.F. Khalil, A. Jones and R.A. Bray (Eds.), Keys to the Cestode Parasites of Vertebrates. CAB International, Wallingford, pp. 257-293.

Rego A.A., de Chambrier A., Hanzelová V., Hoberg E., Scholz T., Weekes P., Zehnder M. 1998: Preliminary phylogenetic analysis of subfamilies of the Proteocephalidea (Eucestoda). Syst. Parasitol. 40: 1-19.

Schmidt G.D. 1986: CRC Handbook of Tapeworm Identification. CRC Press, Boca Raton, 675 pp.

Scholz T., de Chambrier A., Beletew M., Mahmoud Z.N. 2009: Redescription of Proteocephalus glanduligerus (Janicki, 1928) Fuhrmann, 1933 (Cestoda: Proteocephalidea), a parasite of Clarias catfishes in Africa with a unique glandular apical organ. J. Parasitol. 95: 443-449.
Scholz T., Hanzelová V. 1998: Tapeworms of the genus Proteocephalus Weinland, 1858 (Cestoda: Proteocephalidae), parasites of fishes in Europe. Studie AV ČR, No. 2/98, Academia, Prague, $119 \mathrm{pp}$.

Scholz T., Hanzelová V., Š́keříková A., Shimazu T., Rolbiecki L. 2007: An annotated list of species of the Proteocephalus Weinland, 1858 aggregate sensu de Chambrier et al. (2004) (Cestoda: Proteocephalidea), parasites of freshwater fishes in the Palaearctic Region, their phylogenetic relationships and key to identification. Syst. Parasitol. 67: 139-156.

Scholz T., ŽĎárské Z., de Chambrier A., Drábek R. 1999: Scolex morphology of the cestode Silurotaenia siluri (Batsch, 1786) (Proteocephalidae: Gangesiinae), a parasite of European wels (Silurus glanis). Parasitol. Res. 85: 1-6.

Sullivan J., Lundberg J., Hardman M. 2006: A phylogenetic analysis of the major groups of catfishes (Teleostei: Siluriformes) using ragl and rag2 nuclear gene sequences. Mol. Phylogenet. Evol. 41: 636-662.

Verma S.C. 1926: On a new proteocephalid cestode from an Indian fresh-water fish. Allahabad Univ. Stud. 2: 353-362.

Verma S.C. 1928. Some cestodes from Indian fishes, including four new species of Tetraphyllidea and revised keys to the genera Acanthobothrium and Gangesia. Allahabad Univ. Stud. 4: 119-176.

WoodLand W.N.F. 1925: On three new proteocephalids (Cestoda) and a revision of the genera of the family. Parasitology 17: 370394.

Accepted 14 July 2011 